\title{
An Analysis of Factors Influencing Customers' Willingness to Participate in Value Co-Creation of Indonesian Denim Brand Community (Case Study: Darahku Biru)
}

\section{Vanessa Avila Chrisdira, Annisa Rahmani Qastharin, and Lidia Mayangsari}

School of Business and Management, Institut Teknologi Bandung - Indonesia

\section{Abstract}

The problem statement relies on how fashion industry's positive trends affect fashion brands like Sukku Collective to compete with their competitors. A number of studies mentioned that building a profitable relationship between a firm and its customers to create value, or well-known as value co-creation, is a proven way for fashion brand owners to innovate and differentiate the brand in the market. Since participation is the key performance of brand community, the aim of this thesis is to study what factors affecting customers' motivation to participate in brand community's value co-creation of

Corresponding Author: Vanessa Avila Chrisdira vanessa.chrisdira09@gmail.com

Received: 7 February 2020 Accepted: 9 March 2020 Published: 23 March 2020

Publishing services provided by Knowledge E

(c) Vanessa Avila Chrisdira et al. This article is distributed under the terms of the Creative Commons Attribution License, which permits unrestricted use and redistribution provided that the original author and source are credited.

Selection and Peer-review under the responsibility of the ICE-BEES 2019 Conference Committee. Indonesian denim brand community. In order to comply this objective, the author uses Darahku Biru, the first and biggest denim brand community in Indonesia. The variety of members and the size of brand community will help the researcher to learn about customers' willingness to participate in value co-creation of denim brand community in general scope.

In this study, the researcher developed seven hypothesis to analyze the influence factors. Data was collected using online questionnaire which was distributed to 133 Darahku Biru's members using convenience sampling. The data were analysed using Multiple Linear Regression to identify the correlation. Based on analysis, only community atmosphere and community experience have significant influence to customers' willingness to participate in brand community's value co-creation. The findings is expected to help fashion business owners and marketeers to increase the effectiveness of brand community and revitalize the existing brand community.

Keywords: Value Co-Creation, Customer Involvement, Brand Community, Competitive Advantage

\section{Introduction}

As the contributor of creative economy GDP, fashion industry shows impressive growth within the past year. A study shows that the export YoY value increased from $\$ 11.8$ million to $\$ 12.4$ million from 2016 to 2017 . These upward trends also appeared on investment value in textile sector, which escalated to from $61.4 \%$ in 2016 to $68 \%$ in 2017 . In addition, 
the balance trade grew by $1.7 \%$ from $\$ 3.67$ billion in 2016 to $\$ 3.73$ billion 2017 . As a result, the employment rate surged by 0.13\% from 2016 and 2017 (Global Business Guide Indonesia, 2018).

The continuation of Indonesia's fashion industry positive trends spells opportunity for many brand owners in Indonesia to grow. As the number of fashion brand grows, the present condition of the fashion industry leads to the rise of competitive level of fashion brands in Indonesia. In order to compete, there's urgency to enhance motivation and innovation that are in line with industry needs (Badan Ekonomi Kreatif Indonesia, 2018). In this context, having a strong brand identity by adding value through differentiation is seen as a key consideration. The goal of key differentiation is to highlight the company's most powerful values or attributes that competitors can't claim and more valuable for customers (Llopis, 2017).

Previous scholars argued that building a profitable relationship between a firm and its customers is a proven way for fashion brand owners to create sustainable value that allows them to differentiate the brand in the market, which later introduced value cocreation concept. By definition, co-creation is defined as joint creation of value by the company and the customer, which allows the firms to create high-quality interactions that enable the customer to have active dialogue and co-create unique experiences with the company. By this statement, it means that the term of value co-creation shifts the customers' position from external parties to get involved in value co-creation process. (Prahalad \& Ramaswamy, 2004). Having customer involvement in our brand can help the firm to co-create value, co-create competitive strategy, and also collaborate in the firm's innovation process (Schau, Muñiz Jr., \& Arnould, 2009). Furthermore, value co-creation are related to commitment, trust and loyalty (Hsieh, 2017)

Instead of investing in product differentiation, value needs to be created by creating experiences and maintaining consumer-brand relationship in form of brand community (Hamzah, Syed Alwi, \& Othman, 2014). Value co-creation enables the company to generate new ideas and perspectives from customers, which helps the company to improve the current brand attributes and to optimize the marketing campaign to targeted customers (Schau, Muñiz Jr., \& Arnould, 2009). In addition, consumer-generated content can help the company to do product modification and development, also improving the marketing strategy in terms of marketing campaign and brand-building strategies as well (Madupu \& Cooley, 2010). It is also mentioned that brand image of a firm is enhanced by the exchange of customers with like-minded people as the result of value co-creation in form of brand community (Woisetschäger, 2008). 
As already mentioned, brand community involves customers' perspective to create value. Therefore, customers' participation is the key success of creating effective value co-creation in form of brand community (Madupu \& Cooley, 2010). In this context, the increase of customers' involvement means higher chance of company to develop product that close to what customers really want (Thompson \& Sinha, 2008). By understanding the customers' participation in brand community, it helps the company to generate fresh ideas for growing business (Fournier \& Lee, 2009) and extend the life of the brand (Madupu \& Cooley, 2010).

\section{Literature Review}

\subsection{Brand Community}

Brand community is recognized as a group of people, which consists of users and consumers, who are linked to the company that generally exchange and share the experience, knowledge, and information regarding the usage of firms' offering. They interact to develop social capital and social identity (Nambisan \& Baron, 2010), which makes shared value and experience are the core concept of brand community identification (Schau, Muñiz Jr., \& Arnould, 2009).

\subsection{Value Co-Creation}

The concept of value co-creation is introduced in numerous studies as the collaboration between customers and firms to cooperatively create value (Tseng \& Chiang, 2016). In Tseng and Chiang's study, they believed that value co-creation enables firms and customers to consolidate their capacities and work development, design, and promotion of new products utilizing the field of the tourism industry as the study case. At the end of the study, Prahalad and Ramaswamy also suggested shifting company's point of view from firm-centric to customer-centric by involving customers in value creation process will be considered as a great option in order to survive by increasing efficiency.

\subsection{Factors of Customers Willingness to Participate in Brand Com- munity's Value Co-Creation}

Past studies have mentioned about factors influencing customers to join value cocreation of brand community. Brand community is well-known as social cognition involves three-dimension of the interaction model, which are subject factor, environment 
factor, and brand factor (Zhao, Chen, Zhou, \& Ci, 2018). Subject factor claims that selfefficacy and outcome expectation are positively related to customers' willingness to participate in denim brand community's value co-creation. Correspondingly, the concept of self-efficacy refers to the ability of the individual to produce desired effects, which impact individuals' decisions in terms of activities, effort, persistence, and achievement (Flammer, 2001), while outcome expectation is defined as personal beliefs as to the impact of an action on the accomplishment of a particular result/outcome (Lippke, 2017). Environment factor claims that community atmosphere, community experience, and community trust are positively related to customers' willingness to participate in denim brand community's value co-creation. The community atmosphere is defined as the contextual circumstance that involves organizational members ' thoughts, feelings and behaviours (Zhao, Chen, Zhou, \& Ci, 2018). Community experience refers to the overall feeling and impression towards the brand community, member, its offering, including products, services, and interaction (Schmitt, 1999). Community trust is defined as the conviction that the virtual brand network is definitive and equity; a solid conviction that different individuals or the network itself can bring himself/herself a few interests (Ridings, Gefen, \& Arinze, 2002)

Brand factor implies that brand recognition and brand loyalty have significant relationship with dependent variable. Brand recognition is the degree to which a buyer can accurately recognize a specific item or administration just by survey the item or administration's logo, slogan, bundling or publicizing effort, which is related to brand awareness (Rouse, 2019). Brand loyalty refers to the inclination of customers to constantly buy one brand's items over another. Shopper standards of conduct exhibit that buyers will keep on purchasing items from an organization that has encouraged a confiding in the relationship (Trackmaven, 2014).

\section{Methodology}

\subsection{Research Design}

This research applies a quantitative method using distributed Likert Scale questionnaire from 1-5 to test whether the developed hypothesis; self-efficacy, outcome expectation, community atmosphere, community experience, community trust, brand recognition, and brand loyalty have significant relationship with customers' willingness to participate in denim brand community's value co-creation. To analyze the data, the author uses classical assumption data and multiple linear regression analysis 


\subsection{Research Hypothesis}

There are 7 developed hypothesis that the researcher aims to test whether these hypothesis have significant relationship to customers' willingness to participate in denim brand community's value co-creation, which are; H1: Self-efficacy is positively related to customers' willingness to participate in denim brand community's value co-creation, $\mathrm{H} 2$ : Outcome expectation is positively related to customers' willingness to participate in denim brand community's value co-creation, H3: Community atmosphere is positively related to customers' willingness to participate in denim brand community's value cocreation, $\mathrm{H} 4$ : Community experience is positively related to customers' willingness to participate in denim brand community's value co-creation, H5: Community trust is positively related to customers' willingness to participate in denim brand community's value co-creation, H6: Brand recognition is positively related to customers' willingness to participate in denim brand community's value co-creation, $\mathrm{H7}$ : Brand trust is positively related to customers' willingness to participate in denim brand community's value cocreation

\subsection{Conceptual Framework}

The conceptual framework of this study involves 7 hypotheses, namely self-efficacy, outcome expectation, community atmosphere, community experience, community trust, brand recognition, and brand loyalty as independent variables. All of these variables are assumed to have a significant impact on customers' motivation to join the denim brand community's value co-creation as dependent variables. These assumptions are described in the conceptual framework, which can be seen in Figure 1.

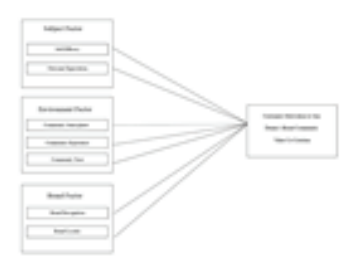

Figure 1: Conceptual Framework. 


\subsection{Data Collection}

This research takes focus on gathering 133 respondents using convenience sampling who pass the requirement of participating in Darahku Biru, which is following or subscribing at least 1 community platform of Darahku Biru; online forum, online magazine, Instagram (@darahkubiru and @darahkubiru_pahi), event (online/@walloffades or offline), and twitter (@darahkubiru) to make sure that they're listed in this community. The data will be collected from May to June 2019 with quantitative approach using questionnaire. The sample size is determined by using Slovin Method. The formula is $n=N /\left(1+\mathrm{Ne}^{2}\right)$ where $n$ is the sample size, $N$ is the population size, and $e$ is the margin of error. By using this formula, the sample size of this study is 99,82599 or 100 respondents.

\subsection{Data Analysis}

In order to answer the hypothesis, the research use multilinear regression method by f-test and t-test. The objective of the research is to investigate influencing factor of customers' willingness to participate in denim brand community's value co-creation. The classical assumption test is performed to test whether data can be used or not to be analyzed by multi-linear regression. There are 5 types of tests to be done on the classical assumption test, including:

1. Normality Test: Normality test is used to analyze whether the data sets are normally distributed or not. In Multiple Linear Regression, the errors between the observed predicted value and observed data needs to be normally distributed.

2. Multicollinearity Test: Multicollinearity test is used to define whether the independent variables are related from one to another or not. In Multiple Linear Regression, no multicollinearity will be founded in data sets.

3. Heteroscedasticity Test: Heteroscedasticity test is used to make sure that inconstancy of a variable is unequal over the scope of estimations of a second factor that predicts it. It can be seen by looking at the pattern of data distribution.

4. Auto Correlation Test: Autocorrelation test is a statistical portrayal of the level of likeness between a given time arrangement and a slacked adaptation of itself over progressive time interims. 
5. Linearity Test: Linearity test is used to analyze the model of datasets. Great research of linear regression, there ought to be a straight connection between the dependent variables and independent variables.

To prove the association between a dependent variable and two or more independent variables, the multiple linear regression is used as predictive analysis. Multiple linear regression allows the researcher to assess the relationship of hypothesis as independent variable with customers' willingness to participate in denim brand community's value co-creation as dependent variable, along with the degree of influence of the hypothesis to dependent variables as well. Using the written assumption, datasets will proceed using multiple linear regression analysis since the author aims to test the relationship between independent variables and dependent variable.

\section{Findings and Argument}

In this study, the researcher uses 133 valid data which is gathered through questionnaire as the research instrument with 5-point Likert Scale using convenience sampling (nonprobability sampling). The analysis of this study is divided into two areas, which are (a) descriptive analysis that explains the demographic and behaviour of respondents as the participant of Darahku Biru, along with the activities in Darahku Biru as well, (b) multiple linear regression analysis that explains the relationship of hypothesis as independent variables with customers' willingness to participate in denim brand community's value co-creation as dependent variables, which is divided into scale measurement, inferential analysis, and multiple linear regression analysis.

\subsection{Descriptive Analysis}

Based on analysis, Darahku Biru's participants are dominated by men with $97.7 \%$. On the other side, only $2.3 \%$ of total respondents are women. This research gathers 133 respondents that come from four different age segments, which are dominated by respondents from age 16-20 years old (46\%), followed by respondents from age 2125 years old (41\%), 26-30 years old (10\%), and above 30 years old (3\%) respectively. From total respondents, $0,902 \%$ or 120 of 133 respondents are pursuing bachelor degree, followed by $0,075 \%$ are pursuing high school diploma, 0,015\% are employee, and $0,008 \%$ are pursuing master degree. Based on monthly income, 35 out of 133 respondents (26.3\%) have more than IDR 5,000,000 as their monthly income, followed 
by $1,000,000-2,500,000$ (25,6\%), $2,500,000-3,500,000(14,3 \%)$, and $3,500,000-$ $5,000,000(12 \%)$.

\subsection{Behaviour Analysis}

From 133 respondents, $32.3 \%$ of them are categorized as new participants ( $<1$ year), followed by $30.8 \%$ of total respondents are coming from respondents who joined Darahku Biru for 1-3 years, followed by $21.1 \%$ of them are coming from respondents who joined Darahku Biru for 4-6 years, and the rest of it are coming from respondents who joined Darahku Biru for more than 6 years. As already stated above, the official criteria of participating in Darahku Biru is following or subscribing for at least 1 community platform that already provided by Darahku Biru, which are online forum, online magazine, Instagram (@darahkubiru and @darahkubiru_pahi), event (online/@walloffades or offline), and twitter (@darahkubiru) to make sure that they're listed in this community. It shows the proportion of followed community platform from 133 respondents. This chart indicates that $88 \%$ of total respondents are following Instagram (@darahkubiru), while 63.2\% of them are following Instagram (@darahkubiru_pahi), 62.4\% are following or attending Wall of Fades, biggest annual denim event made by Darahku Biru, $60.9 \%$ are active in online forum, $19.5 \%$ are subscribing Darahku Biru's online magazine, and $15 \%$ of them are following Twitter (@darahkubiru).

The analysis also reflects that most of respondents $(28,76 \%)$ utilize Darahku Biru as the platform to search and exchange for informations that related to denim industry, whereas $27,05 \%$ of total respondents have discussion with other members about certain topics, whether it's about the denim industry, denim brands, something that happens in the community, or daily conversation. In Darahku Biru's online forum, you can find numerous sections based on topics that related to that section, for example 'news and event' section, 'basic conversation' section, 'apparel' section, 'denim market' section, and even 'legit check' section to assess whether the featured products are fake or not. Each section has its own moderator, along with the description of its section to prevent misleading topics. Furthermore, $13.69 \%$ of respondents exchange their opinions, develop ideas, create, and innovate with other members regarding certain denim brands. Related to previous activities, $12.67 \%$ of respondents use Darahku Biru as a way to gather information and ideas to innovate their brands. These kinds of opinions will help the denim brands owners, especially the local one, to develop their ideas.

It also indicates that $9.24 \%$ of total respondents are giving and looking for information about denim brands, $1.36 \%$ of total respondents are silent readers, $0.034 \%$ of total 
respondents use Darahku Biru to gather and create content for social media activation, and the other $0.034 \%$ of total respondents purchase and sell their preloved or secondhand denim.

\subsection{Classical Assumption Test}

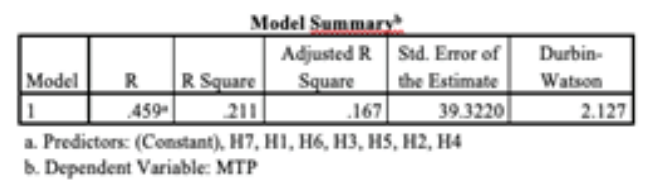

Figure 2: Multiple Linear Regression.

Based on Figure 2, it shows that only $21.1 \%$ of independent variables of variation of customers' willingness to participate in denim brand community's value co-creation can be explained by self-efficacy, outcome expectation, community atmosphere, community experience, community trust, brand recognition, and brand loyalty. Thus, there are other factors that influences customers' willingness to participate in denim brand community's value co-creation that illustrates another $78.9 \%$. There's verifiable study mentioned about factors influencing customer-brand relationship from the perspective of online brand communities that focuses on value-co creation process into 4 factors, which are interaction, utilitarian experience, hedonic experience, and relationship of each member in community (Hsieh, 2017). Hsieh (2017) also added that value co-creation is strongly related to brand commitment and brand trust, which can be considered as additional factors for further research in the future.

In online brand community engagement dimension into 11 factors, which are brand influence, brand passion, connection between members, degree of each member wants to help the other member, like-minded discussion, rewards (hedonic and utilitarian), degree of each member wants to receive help from fellow community members, degree of self-expression, up-to-date information, and validation of their opinions, ideas, and interests (Baldrus, Voorhees, \& Calantone, 2015), which can be used as the additional factors that explain dependent variable.

\subsection{F-Test}

Based on the score of F-value and Sig., there's a simultaneously significant impact of self-efficacy, outcome expectation, community atmosphere, community experience, community trust, brand recognition, and brand loyalty to customers' willingness to 


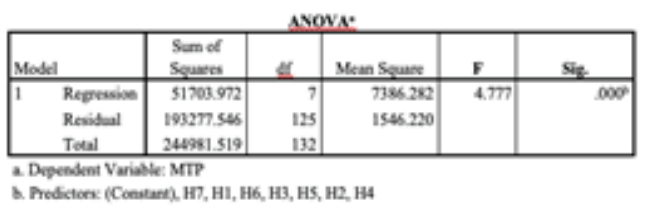

Figure 3: F-Test.

participate in denim brand community's value co-creation since the F-value is higher than $1.77(4.777>1.77)$ and the significant value is lower than 0.05

\subsection{Hypothesis Analysis}

TABLE 1: Hypothesis Analysis.

\begin{tabular}{|c|c|c|c|c|}
\hline Hypetionth & A. Votert & t. Voller & prater & Rentit \\
\hline 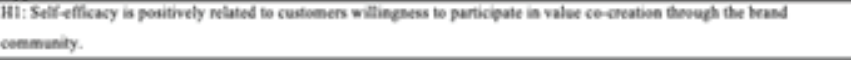 & 1.948 & 0.097 & o.sn & Rojosted \\
\hline 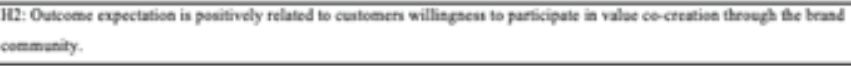 & 0.569 & .0 .44 & $0.05 s$ & Rejested \\
\hline 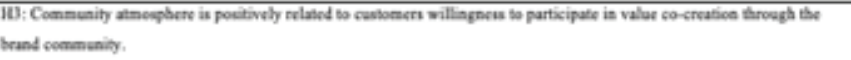 & .7 .083 & .3951 & $\infty \infty$ & Accepted \\
\hline 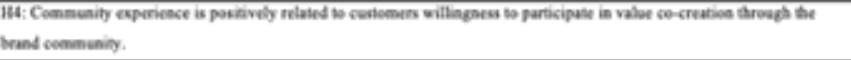 & 3.114 & 2137 & 0.015 & Aoseppted \\
\hline 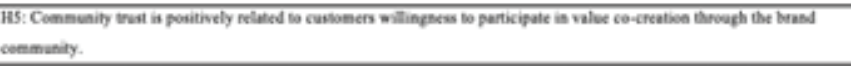 & 2069 & 1.050 & 0.003 & Rojoctod \\
\hline 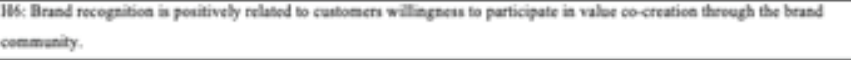 & 0.592 & 0.459 & 0.861 & Rejested \\
\hline 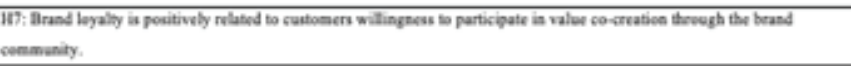 & 1.545 & 0.507 & 0.366 & Rosisted \\
\hline
\end{tabular}

Based on the calculation on Table 1, it can be concluded that community atmosphere and community experience are positively related to customers' willingness customers' willingness to participate in denim brand community's value co-creation. Therefore, $\mathrm{H} 3$ and $\mathrm{H} 4$ are accepted. Since both of these factors are included in environmental factors, it can be concluded that environmental factors need to be the main consideration for brand community to increase the effectiveness and revitalize brand community. Environmental factors refer to the atmosphere and experience of brand community, which involves active dialogue and personalized experience among each member.

Since the conceptual framework model is adapted from Zhao et al (2018), comparison of the result of this study is needed. Based on Zhao et al (2018) study, environmental factors (i.e community experience and community trust) have significant influence to customers' willingness to participate. However, community atmosphere is not positively related to customers' willingness to participate. The slight difference of this study can be affected by other factors, such as the respondents of study. Zhao et al (2018) divides the respondents based on gender, age, and education. $58.8 \%$ of the respondents are men, most of the respondents are 18-25 years old, and come from bachelor degree as 
the level of education. Using convenience sampling, $97.7 \%$ of total respondents of this research are men living in Indonesia. Most of respondents come from aged between 21-25 years old, bachelor degree, having monthly income more than IDR 5,000,000 per month, and pursuing bachelor degree. The difference in location, age, and gender, with additional factor, which is income, creates difference of this study. However, the profile of respondents matches Sukku Collective's target market, which is men who aged 18-25 years old with income more than IDR 5,000,000 per month, which creates no issues. Previous study also mentioned that gift and experience of sharing are the main component of brand community (Pongsakornrungsilp \& Schroeder, 2011), which explains the result. Since the t-values of self-efficacy, outcome expectation, community trust, brand recognition, and brand loyalty are lower than 1.97 and the Sig value of these factors are higher than 0.05, it can be concluded that there's no significant relation between self-efficacy, outcome expectation, community trust, brand recognition, and brand loyalty. Therefore, $\mathrm{H1}, \mathrm{H} 2, \mathrm{H} 5, \mathrm{H} 6$, and $\mathrm{H} 7$ must be rejected. The explanation can be summarized to Table 1.

\section{Conclusions}

The objective of this study was to understand factors that influence customers' willingness to participate in denim brand community's value co-creation. There are 7 factors that the researcher used to test the relationship between these factors and customers' willingness to participate in denim brand community's value co-creation, which are self-efficacy, outcome expectation, community atmosphere, community experience, community trust, brand recognition, and brand loyalty. From these factors, only community experience and community atmosphere that have significant relationship with customers' willingness to participate in denim brand community's value co-creation. Community experience and community atmosphere are proven as factors driving customers' willingness to participate in denim brand community's value co-creation. Community atmosphere reflects the degree to which customers want to be able to express their opinions and ideas freely, also be able to innovate and collaborate with fellow members, while community experience refers to the overall feeling and impression towards the brand community, member, its offering, including products, services, and interaction, which is related to customers' ability to get and share valuable information, interact with fellow members in community, participate in brand community's activities, also willingness to create value together. Since 5 other factors are rejected, this study finds that there are other indicators that company needs to considers in order to build 
effective brand community other than community atmosphere and experience, which requires further studies.

\subsection{Suggestion}

Due to data collection method and time limitation, there are numerous limitation that can be used as recommendation for further research, as follows:

1. Since the researcher decides to use convenience sampling, there's a gap between the number of respondents and the result of gender and age analysis. In demographic profile, $97.7 \%$ of total respondents are men and $90.2 \%$ are currently pursuing bachelor degree. Same thing happen to community behaviour, where $88.7 \%$ of total respondents are member of brand community. Therefore, there's a need for further research to broaden the range of study, in terms of gender, education, and users' role in brand community. Therefore, the data will represent all of target segment of Sukku Collective's brand community.

2. This study takes focus on developing 7 factors that affect customers' willingness to participate in denim brand community's value co-creation, which are selfefficacy, outcome expectation, community atmosphere, community experience, community trust, brand recognition, and brand loyalty. However, only $21.1 \%$ of independent variables of variation of customers' willingness to participate in denim brand community's value co-creation can be explained by self-efficacy, outcome expectation, community atmosphere, community experience, community trust, brand recognition, and brand loyalty. Thus, there are other factors that influences customers' willingness to participate in denim brand community's value co-creation that illustrates another $78.9 \%$.

\section{References}

[1] Global Business Guide Indonesia, "Indonesia's Garment and Textile Sector: Remain Optimistic Amid Mounting Pressure," 2018. [Online]. Available: http://www.gbgindonesia.com/en/manufacturing/article/2018/ indonesia_s_garment_and_textile_sector_remain_optimistic_amid_mounting_pressure_11879. php.W258W9174

[2] Badan Ekonomi Kreatif Indonesia, "RETAS - Bangkitnya Label Lokal," June 2018. [Online]. Available: http://webcache.googleusercontent.com/search?q=cache: 
C6rdqg5AkVwJ:www.bekraf.go.id/downloadable/pdf_file/180799-retas-vol-7-juni2018-bangkitnya-label-lokal.pdf+\&cd=8\&hl=en\&ct=clnk\&gl=id.W258W9174

[3] E. Llopis, "A Strong Brand Conveys Confidence and Competitiveness," 20 January 2017. [Online]. Available: https://www.ie.edu/insights/articles/strong-brand-conveysconfidence-and-competitiveness/.W258W9174

[4] C. Prahalad and V. Ramaswamy, "Co-Creation Experiences: The Next Practice in Value Creation," Journal of Interactive Marketing Volume 18 / Number 3 / Summer 2004, pp. 6-13, 2004. W258W9174

[5] H. J. Schau, A. M. Muñiz Jr. and E. J. Arnould, "How Brand Community Practices Create Value," Journal of Marketing 30 Vol. 73, p. 30, September 2009. W258W9174

[6] P.-L. Hsieh, "Factors Influecing Consumer-Brand Relationships from the Perspective of Online Brand Communities," Journal of e-Business, pp. 117-146, 2017. W258W9174

[7] Z. Hamzah, S. Syed Alwi and M. Othman, "Designing corporate brand experience in an online context: A qualitative insight.," Journal of Business Research, vol. 67, no. 11, pp. 2299-2310, 2014. W258W9174

[8] V. Madupu and D. O. Cooley, "Antecedents and Consequences of Online Brand Community Participation: A Conceptual Framework," Journal of Internet Commerce, pp. 1-21, 2010. W258W9174

[9] D. M. Woisetschäger, "How to Make Brand Communities Work: Antecedents and Consequences of Consumer Participation," Journal of Relationship Marketing, p. 18, 2008. W258W9174

[10] S. Thompson and R. Sinha, "Brand communities and new product adop- tion: The influence and limits of oppositional loyalty," Journal of Marketing, vol. 72, no. 6, pp. 65-80, 2008. W258W9174

[11] S. Fournier and L. Lee, "Getting brand communities right," Harvard Business Review, vol. 87, no. 4, pp. 105-111, 2009. W258W9174

[12] S. Nambisan and R. Baron, "Virtual Customer Environments: Testing a Model of Voluntary Participation in Value Co-Creation Activities," J.Prod. Innov. Manage, pp. 554-572, 2010. W258W9174

[13] F. Tseng and L. Chiang, "Why does customer co-creation improve new travel product performance," Journal of Business Research, vol. 69, no. 6, pp. 2309-2317, 2016. W258W9174

[14] Y. Zhao, Y. Chen, R. Zhou and Y. Ci, "Factors influencing customers' willingness to participate in virtual brand community's value co-creation," Online Information Review, pp. 2-12, 2018. W258W9174 
[15] A. Flammer, "Self-Efficacy," in International Encyclopedia of the Social \& Behavioral Sciences, Amsterdam, Elsevier, 2001, pp. 13812-13815.W258W9174

[16] S. Lippke, "Encyclopedia of Personality and Individual Differences," 2017. [Online]. Available: https://link.springer.com/referenceworkentry/10.1007\{\%\}2F9783-319-28099-8_1145-1.W258W9174

[17] B. Schmitt, "Experiential marketing," Journal of Marketing Management, vol. 15, no. 1-3, pp. 53-67, 1999. W258W9174

[18] C. Ridings, D. Gefen and B. Arinze, "Some antecedents and effects of trust in virtual communities," The Journal of Strategic Information Systems, vol. 11, no. 3, pp. 271295, 2002. W258W9174

[19] M. Rouse, "Brand Recognition," 2019. [Online]. Available: https:// searchcustomerexperience.techtarget.com/definition/brand-recognition. W258W9174

[20] Trackmaven, "Brand Loyalty," 2014. [Online]. Available: https://trackmaven.com/ marketing-dictionary/brand-loyalty/.W258W9174

[21] B. J. Baldrus, C. Voorhees and R. Calantone, "Online brand community engagement: Scale development and validation," Journal of Business Research, 2015. W258W9174

[22] S. Pongsakornrungsilp and J. Schroeder, "Understanding value co-creation in a co-consuming brand community," Marketing Theory, vol. 11, pp. 303-305, 2011. W258W9174 